\title{
The Strategy of Enhancing Student's Leadership Behavior through History Learning Based on Serat Mudhatanya Value
}

\author{
Aris Cahyono*; Mulyoto; Leo Agung S \\ Department of Teacher Training and Education, Sebelas Maret University, Indonesia \\ Email: Ariscahyono2121@gmail.com
}

http://dx.doi.org/10.18415/ijmmu.v4i6.100

\begin{abstract}
The aim of this research is to examine the implementation and effectivity of history learning concept based on value of Serat Mudhatanya for enhancing student's leadership behavior. This research is conducted on XI-3 Social Science of SMA Negeri 1 Baureno as the experimental class and XI-3 Social Science of SMA Negeri 1 Sumberrejo as the control class. This research uses the combination of qualitative and quantitative method. The results of this research are: 1) history concept based on value of Serat Mudhatanya is developed by combining Group Investigation concept, Value Clarification Technique and Scientific approach, and leadership values of Serat Mudhatanya, 2) the implementation of history learning based on value of Serat Mudhatanya enhancing character building of student effectively in the form of leadership behavior and student's result of their studies.
\end{abstract}

Keywords: Leadership behavior; Leadership value; History learning concept; Serat Mudhatanya; Character building

\section{Introduction}

Globalization is a phenomenon which is inevitable in the 20th century. Globalization causes good and bad impacts to the human's life. One of the negative impacts of globalization is the emergence of the various phenomena which depicts moral crisis devastating the nation. Su'ud (2008:124) states that nowadays the changing of values in Indonesian society tend to cause ethical and moral decadency. This condition portrays that society behavior increasingly worse from Indonesian noble values which known as unusually intensive, outstanding and lofty. Lickona in Muslich (2011: 35-36) provides 10 indications which are: 1) increasing number of violence among adolescence; 2) degenerating of language and word that is being used; 3) predisposing peer group about the violence; 4) increasing self-destructive behavior such as the use of drugs, alcohol and promiscuity; 5) obscuring good and bad moral reference; 6) decreasing work ethics; 7) considering honor for parents and teachers; 8) lack of responsibility as individual and citizen; 9) espousing dishonesty; and 10) existing of distrustfulness and hatred among others. All of ten indications above currently occur in Indonesia.

Students is agent of change who are expected to bring Indonesia into a better country. However, the recent phenomena occur do not meet the expectation. In some cases, students are entangled in illegally 
consuming drugs, free sex until brawl act among students which is miserably done by elementary students. This recent issues need to be concerned more by societies. One of the effort for solving that issues is embedding good moral values in learning process. Suryani (2007:71) suggests in order to form meaningful and high value of learning, teachers can use methods which can internalize values in the process of learning.

One of the subject which is laden of values is history. According to Isjoni (2007:71) history is a subject that infusing knowledge and values of the process of changing and progressing Indonesian and world's society in the past to the present time. History value can be found through an ancient manuscriptshaped history. An ancient manuscript-shaped is a historical heritage and patrimonial of culture which becomes an asset and reflects the national identity and local wisdom. Nancy (cited in Margana 2004:42) states that Javanese manuscripts has a prophecies value, a dimension of future which cannot be found in western manuscript.

There is a synergy that can be done between school learning and historical heritage in the form of ancient manuscript-shaped. One of the effort is by outlining the methods of historical learning which is based on the value of ancient manuscript-shaped. Historical learning of the value of ancient manuscriptshaped is based on assumptions: 1) the ancient manuscript-shaped are widely available and distributed throughout Indonesia, by using them on education there is an expectation that young generation can foster sense of belonging and appreciate the history of the nation; 2) the values which is contained on ancient manuscript-shaped can become the stronghold for students in facing the flowing of global cultures and having roles to strengthen the national identity.

Manuscript-based value learning has an advantage in enhancing the character of the students. Sariyatun (2013) provides that the values of local wisdom require a strategic function in forming character building and national identity. Mulyasa (cited in Ramdani 2014: 28-37) provides that the successful implementation of character learning is determined by one aspect, which is leadership in doing planning, practicing and evaluating process concerning a comprehensive character learning.

This research will use Serat Mudhatanya as sources of ancient manuscript-shaped. Serat Mudhatanya is written by Raden Tumenggung Purbadipura, a servant in the Kasunanan Surakarta palace during the reign of Sinuhun Pakubuwana X. Serat Madhatanya contains leadership teachings in the life of society. Serat Mudhatanya contains 8 guidance of leadership which are kuwasa, purba, wisesa, kukum, adil, paramarta, dana and pariksa. Through the implementation of the values in Serat Mudhatanya, the students are expected having a profitable guidance when they participating in family life, neighboring and community.

In learning moderation, the process of embedding values is done by using Value Clarification Technique (VCT). VCT is a learning process which can assist students in figuring and determining values which are considered as good values. Smith and Spranger (cited in Abdurrahmansyah: 2004) provide that the values determine individual's attitudes and actions therefore they should be possessed. VCT assists students in enhancing attitudes, values and morals in facing the cases presented by the teachers. Djahiri (1985) concludes the purpose of VCT is to train and manage students about how to assess and take decisions of the general values thereafter implement them as a member of society. Some of educational experts suggest that VCT is the most efficiency method of value learning which is more excessive compared to other methods and approaches (Cheppy, 1998 cited in Adisusilo 2013:113).

History learning is not only using VCT method but also combine VCT with Group Investigation method. Group Investigation method allows students to have interaction to each other in the learning process in the classroom. Group Investigation method applies the method which occurs in the society into the classroom, specifically on how society members engage in social process mechanism through a social agreement. By using the agreement, the students learn academic knowledge and involve in social problem solving (Soekamto and Winataputra 1996: 106). The other advantage in using Group Investigation is the 
students can be independence in learning process. The students can increase their selves' believe, their thoughts to evolve the information they receive from any sources, to solve and accomplish issues, thus all group members comprehend (Moedjiono, 1991: 140).

In addition, there is a scientific approach that is used to complete VCT and Group Investigation. Scientific approach is a technique in formulating questions and answers through observations and experiments. There are activities which are observed in this approach such as examining, questioning, exploring, associating and communicating (Kemendikbud 2013: 208). The used of this approach is suggested on each learning process in the classroom based on curricula 2013.

\section{Method}

This research uses combination method. According to Creswell (2009) combination method is an approach which combining or relating qualitative and quantitative method. By combining qualitative and quantitative method the result is expected more comprehensive, valid, reliable and objective (Sugiyono 2015: 21). Combining method consists of two phases of research which are qualitative research phase and quantitative research phase. Those two phases is done in different time. In the first stage, this research uses qualitative method through observation, interviewing and document analysis. There are three steps of qualitative method using in this research: 1) teachers and students interviewing for determining the level of leadership behavior; 2) doing an observation through history learning process and the media which is used; and 3) document analysis on learning tools or devices which is used by teacher. Thereafter, the qualitative data obtained will be analyzed and used as the hypothesis formulation basis.

Quantitative phase is conducted for examining hypothesis through respondent questionnaire. The respondent in this quantitative phase is 60 students, consist of respondent of experimental class and respondent of control class. Quantitative analysis is conducted by using T-test. T-test is comparing the result of experimental class which use history learning based on Serat Mudhatanya value and control class which use lecturing and discussion method. Quantitative analysis uses instruments whose reliability has been validated and examined.

This research is conducted in SMA Negeri 1 Baureno and SMA Negeri 1 Sumberrejo. The population of this research is the entire class XI of Social Science, consist of 60 students. The samples of this research are two classes, which are XI-3 Social Science of SMA Negeri 1 Baureno as experimental class (history learning based on Serat Mudhatanya value) and XI-3 Social Science of SMA Negeri 1 Sumberrejo as control class (history learning based on group discussion). The sample consists of 30 students from both experimental class and control class. The effectivity of test result can be seen by comparing pre-test and post-test in experimental class and control class.

\section{Discussion and Analysis}

\subsection{Leadership Value of Serat Mudhatanya}

The leader is a person who has skills and qualities, specifically in a certain field thus he is able to influence others to perform certain activity to achieve one or several goals (Kartono, 2005: 33). Sander and Davey (2011) state that the combination of several behaviors of leader will affect to the leadership efficiency in in affecting his followers. In addition, leadership is personal ability in convincing others, specifically his followers. Leadership is the result of social organization that has been formed or as a result of the dynamics of social interaction. 
Goleman (2003: 19) states that leadership style is the way that is used by a person to influence other person or group in order to achieve several goals thus that people or group behaving as desired by the leader (Soekanto, 2000: 318). Basically, leadership style is the pattern of leader's behavior in leading his subordinates to achieve certain goals.

Serat Mudhatanya is a type of serat piwulang. Moertono (1985: 15) states that this manuscript contains mostly about moral lesson. The word Mudhatanya is originated from two words, "mudha" and "tanya". Poerwadarminta (in Baosastra Djawa, 1939: 323) the word "mudha" means "enom" (young) while the word "tanya" means "bertanya" (asking) (Poerwadarminta, 1939: 592). Etymologically, Mudhatanya means a young man who questioning due to his ignorance. This manuscripts is presented in the form of dialogue between two peoples. The issues which have been discussed mostly about ethics and norms, outfitted with leadership story of several prophets (Prophet Muhammad SAW, Prophet Adam, Prophet Daud, Prophet Sulaiman and Prophet Yusuf) and the companions of Prophet Muhammad commonly referred as khulafaur rasyidin (Abu Bakar ash-Shidiq, Umar bin Khatab, Usman bin Affan and Ali bin Abi Thalib). In addition, this manuscript also composed of stories about leadership style of several kings in Java, starting from Kyai Ageng Sela to Paku Buwana VIII.

Serat Mudhatanya is a handwritten manuscript using Javanese letter and New Javanese language type "krama" (polite sentence) and "ngoko" (impolite sentence). This manuscript is written by Raden Tumenggung Purbadipura, a courtier of Bupati Anom Gedhong Tengen in Surakarta at Kamis Legi (one of Javanese calendar matter tradition), 28 Sura (one of Islam monthly calendar), Jimakir 1858 or at July 28,1927 . This manuscript is written by two person, Wagnyaukara and Raden Tumenggung Purbadipura. Wignyaukara writes pages 1-37 while Raden Tumenggung Purbadipura writes pages 59-90. Below is the quotation which explains author of Serat Mudhatanya:

Sêrat Mudhatanya punika, ingkang ngarang Raden Tumênggung Purbadipura, Abdi Dalêm Bupati Anom Gêdhong Têngên ing Surakarta Hadiningrat. Pangarangipun nalika dintên Kêmis Lêgi tanggal kaping 28 wulan Sura taun Jimakir angka 1858 utawi kaping 28 Juli taun angka 1927. Gagriya salêbêting nagari ing kampung Kratonan Kidul, ondêr dhistrik Sêrêngan, sakilène Pasar Gêmblêgan.(Purbadipura, 1927:ix)

This Serat Mudhatanya is written by Raden Tumenggung Purbadipura, a courtier of Bupati Anom Gedhong Tengen in Surakarta Hadiningrat Palace. It is written at Kamis Legi, date 28 month Sura year Jimakor 1858 or July 28, 1927. He lives in Kratonan Kidul village, Serengan district, and west of Pasar Gemblegan. (Purbadipura, 1927: ix).

Serat Mudhatanya manuscript contains the teaching of leadership. This manuscript explains about the leadership in society life which is presented in the form of dialogue between a young man and a cleric. The teaching of leadership in society life discusses about what should be prepared for young generations when they come into family life, neighboring and society life. There are 8 guidances which should be understood by them: kuwasa (authority), purba (responsible), wisesa (firm), kukum (same legal treatment), adil (fair), paramarta (soft hearted), dana (doing charity), pariksa (earnest). Below is the explanation of those 8 guidances.

1. Kuwasa means the authority to decide every issues wisely. Below is the following quote.

Kuwasa: wênang ngewahi tatanan ingkang kirang murakabi dhatêng kulawarga (Purbadipura, 1927:7)

Kuwasa: authorized to change the order that is less beneficial to the family. 
2. Purba means being responsible for all issues that occur in family, society, nation and state. Below is the following quote.

Purba: mêngku dhatêng samukawis agêng alit, amis bacin, èwêt pêkèwêt, gampil angèl, ruwêt rêntên. Sadaya kukubanipun ing ngriku, punika anggèr ingkang kajibah mêngku. (Purbadipura, 1927:7)

Purba: controlling the big and the small, rancid smell (malodorous), difficult - involute, tough - easy, complicated - subtle. You have to control any issue in this area.

3. Wisesa means towards the others and always do good. Below is the following quote.

Wisesa: punika satêngah amêksa dhatêng tindak sae. Angancam-ancam sintên ingkang nglampahi lêpat badhe tampi pamisesa ing samurwatipun nanging saderengipun kêdah dipundhawuhakên. Yen ala bakal nemu ala. Yen becik bakal nemu becik. (Purbadipura, 1927:8)

Wisesa: partially force people to act good. Threatened person who do bad will receive bad result accordingly. Beforehand should be informed. Who does bad will receive bad. Who does good will receive good.

4. Kukum means equal legal treatment to every person. Below is the following quote.

Kukum: kêdah nindakakên ing salêrêsipun. Têgêsipun: botên bahu kapine sintên-sintêna bilih botên lêrês inggih kêdah kalêrêsakên. Manawi mêksa botên purun mantuni tindakipun ingkang awon. Ing ngriku sampun sêdhêngipun katindakakên prakawisipun. (Purbadipura, 1927:8)

Kukum: should act properly. The meaning is dispassionate to any person. Any person who is not correct should be justified. If he still do thing incorrectly, he should be charged.

5. Adil means fair to any person, based on the effort that he has been done. Below is the following quote.

Adil: punika tumrap dhatêng putra wayah sadhèrèk santana abdi agêng alit. Manawi prakawisan rêbat lêrês. Dhatêng sasaminipun putra wayah sadhèrèk santana abdi, kêdah dipuntêtêpakên ing pangadilanipun ingkang jêjêg. Babasan utang nyaur, nyilih ngulihake. Utang lara nyaur lara, utang pati nyaur pati, sapiturutipun. Botên kenging dlemok cung, kêdah wradin.

Têgêsipn yen si dhadhap kang utang, mung nyaur samene, yen si waru kang utang kudu nyaur samene, punika dlêmok cung namanipun. Sampun ngantos makatên, kêdah samisami pamidananipun, sarta kêdah têtêp ingkang sampun kasêbut ing anggèr, anggèr botên kenging mèncèng. (Purbadipura, 1927:8)

Adil: doing fair to children, grand children, family, great and small servant. If the issue is fighting over the truth, a fair trial should be established to all childrens, grand childrens, relatives, families and servants. Proverbial: indebted - paid, borrow - return, indebted sick 
paid sick, indebted life paid life (kind of Javanese idiom), and et cetera. The person should do fair, no dispassionate to certain person.

The meaning is if si Dhadhap indebted money, he should pay this number, if si Waru indebted money, he should pay that number. This action belongs to dispassionate and it is forbidden. The person should obey existing rules and never deviate the rules.

6. Paramarta means gentle and has compassion, patient and forgiving toward others. Below is the following quote.

Paramarta: punika bilih putra wayah sadhèrèk santana abdi gadhah prakawis dhatêng anggèr, ingkang sanès prakawis agêng, kadosta kalentu ing patrap, dêksura, kumasurun, anggêgampil kagunganipun anggèr ingkang botên sapintêna, punika kêdah dipunparingi paramarta. Sampun lajêng katêtêpakên ing kalêpatanipun. Kêdah dipunaring-aringi supados asrêp manahipun. Saupami lêpat sakêdhik kemawon dhatêng angger lajêng kapidana awrat, sarta lajêng kauwus-uwus ingkang botên sampun-sampun, punika botên prayogi. (Purbadipura, 1927:9)

Paramarta: if the childrens, grand childrens, relatives, familie and servants have problems with you, which is not big issue, such as improper attitude, improper manner, indelicate, underestimating your belonging; it should have been apologized. Do not mark the mistakes. You should present serenity to them. The result will not be good if you mark a single mistake and hardly punish them and leverage it continuously.

7. Dana means diligently donating charity using the best provision. Below is the following quote.

Dana: inggih ingkang kêrêp paparing. Manawi paparing barang ingkang enggal risak, kadosta dhahar-dhaharan, sêmbêt sapanunggilanipun, punika kêdah ingkang kêrêp. Manawi paparing barang ingkang sagêd lami kanggenipun kadosta: ingkang warni mas, intên, dhuwung, tumpakan tuwin griya papan semahan. Punika kêdah ingkang awis-awis. (Purbadipura, 1927:9)

Dana: donate your charity oftenly. If donating perishable goods, for example food, clothing, etc., it should be done often. If donating goods for longer usage, for example gold, diamond, keris (Javanese traditional weapon), vehicle and residential home, it should be rarely done.

8. Pariksa means solemnly in conducting monitor and control toward the performance of the subordinates, not simply commanding subordinates but directly monitor in the field. Below is the following quote. 
Pariksa: pikajêngipun inggih ingkang pariksa sayêktos. Têgêsipun ingkang botên kaliyan aturing liyan, ingkang awon ingkang sae anggèr kêdah matitisakên piyambak dhatêng tiyangipun, botên mawi lalantaran utusan sabab utusan punika asring suda wêwah kaliyan nyatanipun. (Purbadipura, 1927:12)

Pariksa means solemnly examined the issue. In this case, he should know the issues by himself and not receive report from other people since others' report frequently different to the reality.

Those 8 guidances above is relevant to the society life nowadays. A young man will become a leader in the future, both leader in family and in society. The status of the leader will influence toward reformation and improvement of the social-economic condition in society. A justice and prosperous society are ascribed from the harmoniuos families who always obey and follow the rules in the society.

\subsection{The Implementation of History Learning Based on Serat Mudhatanya Value for Enhancing Student's Leadership Behavior}

The researcher will examine the implementation of product development in this stage. The examination is conducted in XI-3 Social Science class of SMA Negeri 1 Baureno as the experimental class and XI-3 Social Science of SMA Negeri 1 Sumberrejo as the control class. The implementation of history learning based on Serat Mudhatanya value is a combination of Group Investigation method, Value Clarification Technique and scientific approach using which emphasizing on leadership values of Serat Mudhatanya. There are 6 phases of Group Investigation which are: 1) grouping stage and topic selection; 2) planning stage; 3) investigation stage; 4) organizing stage; 5) presentation stage; and 6) evaluation stage. Scientific approach has 3 stages of learning process: 1) introduction stage; 2) discussion stage (observing, questioning, reasoning, testing and networking); and 3) conclusion stage. VCT approach has 3 stages: 1) selecting; 2) appreciating; and 3) comitting. The courses used in this stage are the system of government, social, economics, and the cultures of Indonesian society during the period of major Islamic empires which influenced the life of Indonesian society today. Below is the explanation.

\subsubsection{First Stage: Phase 1 Scientific (Introduction)}

The learning process is started by praying based on students' believes. Afterward, theacher explaining the course and presenting the purpose of learning by Kompetensi Inti/ KI (core competition) and Kompetensi Dasar / KD (basic competition) which is going to learned by them. The purpose of this activity is the student understand about the course that will be presented for them and the achieve the goal of the course. Teacher aims the students toward the method that will be practiced and explained about the leadership briefly.

\subsubsection{Second Stage: Phase 1 of Group Investigation (Grouping) and Phase 1 of Value Clarification Technique (Selecting)}

Teacher leads student to form 5 studying groups which consist of 6-7 students. Afterward, the teacher arranges arrange topic selection for each group. Each group has been given topic of government system, social, economics and culture of society heritage during the period of Islamic empires in Indonesia. Teacher explains the issue which can evoke students' emotion and enthusiasm. Subsequently, teacher asks some critical questions about the values in Serat Mudhatanya (kuwasa, purba, wisesa, 
kukum, adil, paramarta, dana and pariksa) to students. At last, students are asked to select the value which will be developed based on teacher's explanation.

\subsubsection{Third Stage: Phase 2 of Group Investigation (Planning) and Phase 2 of Scientific (Observing)}

Teacher plans a group discussion and presents information regarding to it. Each group is given each different issue. Afterward, teacher leads students to observe the issue that will be learnt and discussed.

\subsubsection{Fourth Stage: Phase 3 of Group Investigation (Investigation) and Phase 3 of Scientific (Questioning and Reasoning)}

Teacher assigns each group to investigate toward the material or issue that has been given through discussion. Teacher also leads and advises the students to ask questions. In this stage, the students are expected to do reasoning toward the issue.

\subsubsection{Fifth Stage: Phase 4 of Group Investigation (Organizing) and Phase 2 of Value Clarification Technique (Appreciating)}

Teacher encourages students to organize their small groups and appreciate the value they choose. In this stage, teacher observe how is the organization and performance of each group. In this stage, the students who has or does not has leadership behavior can be recognized.

\subsubsection{Sixth Stage: Phase 5 of Group Investigation (Presentation) and Phase 4-5 of Scientific (Testing and Networking)}

Teacher assigns each group to discuss and present their result in front of the class. Teacher collects the result of student's discussion (networking) with their group. In addition, teacher provides and strengthen student's mindset of the leadership value and behavior.

\subsection{Seventh Stage: Phase 6 of Group Investigation (Evaluation) and Phase 3 of Value Clarification Technique (Committing)}

Teacher evaluate the course of discussion, leads students to commit and repeat their behavior based on the value they choose to be applied in the life of the society. Teacher provides clarification of the values based on the theme presented by the groups, such as the value of heroism, nationalism, leadership, discipline, and others. Afterward, teacher assigns a group discussion report to create a paper as homework and will be submitted in the next meeting. 


\subsection{Eighth Stage: Phase 7 of Scientific (Conlcusion)}

Teacher and students conclude the discussion. In addition, teacher provides and strengthens values. Teacher also provides reinforcement to implement values and leadership behavior in social life then group discussion is finished by praying.

Comprehensively, the observation conducted by researcher shows that teacher can stimulate toward the beginning of learning activity by displaying pictures that appropriate to the topic or issue of Mataram Empire to Kasunanan Surakarta as the palace and other things. Teacher explains the outline of the learning material based on core and basic competition which can encourage student to be more concerned to the learning process.

At the core stage of activity, teacher can organize all members in groups' discussion which consist of 6 groups. Through observation conducted by researcher, the use of learning method can maximize the role of all members in the group. Teacher guides and directs students to create a good cooperation between students, as well as students with teacher. At the implementation stage, the students are really enthusiastic by choosing and uttering their opinions and providing examples of concrete values in everyday life.

At the conclusion stage of learning process, students actively provide conclusions and answer the questions about the leadership which has been uttered by teacher. Students are able to explain the values in Serat Mudhatanya and its implementation in the society life. At last, teacher explains their homework in the form of essays and material outlines for the next meeting.

\subsection{The Effectiveness of Historical Learning Based on Serat Mudhatanya Values in Enhancing Student's Leadership Behavior}

To determine the level of success or effectiveness of a study required a test. The effectiveness of method of historical learning process is conducted by experimental activities. The experiment is conducted toward XI-3 Social Science of SMA Negeri 1 Baureno as the experimental class and XI-3 Social Science of SMA Negeri 1 Sumberrejo as the control class. The effectiveness test is divided into two categories, namely the result of the learning test and the leadership behavior questionnaire. In this test, the data used are post-test result of experiment and control class. The effectiveness test is conducted by using independent t-test. First, the effectiveness of the test toward the test result. The data obtained is processed using independent t-test through SPSS19 program. The data should be normally distributed and homogeneous before independent t-test is conducted. In the normality test, the result of significance of experimental class is 0.642 while control class is 0.172 . These two data are normally distributed due the level of significance is greater than $0.05(0.642>0.05$ and $0.172>0.05)$. In the homogeneity test, the result is obtained a significance of 0.241 . The data is homogenous due the level of significance is greater than $0.05(0.241>0.05)$. In independent $t$-test, the result of significance is 0.000 , both classes are said to have significant differences due to the level of significance is smaller than $0.025(0.000<0.025)$.

Second, The effectiveness of the test toward the leadership behavior. The data obtained is proceeded using independent t-test of SPSS19. The data should be normally distributed and homogenous before independent $t$-test is conducted. In normality test, the result of significance of experimental class is 0.922 while control class is 0.779 . Those two data are normally distributed due to the level of significance is greater than $0.05(0.922>0.05$ and $0.779>0.005)$. On the homogeneity test, the significance of the data is 0.261 . Therefore, the data is homogeneous due the level of significance is greater than $0.05(0.261>$ 0.05). In independent $t$-test, the level of significance is 0.001 . Due to that reason, the experimental class and control class are said to have a significance differences (the level of significance is smaller than 0.025 $(0.001<0.025))$. By looking at the result, it can be stated that experimental and control class have 
significance differences in both learning ability and leadership behavior state. Therefore, history learning based on Serat Mudhatanya value which is applied to experimental class more effective, can improve leadership behavior and learning test result compared to the learning method applied in the control class.

\section{Conclusion}

Globalization is a common phenomenon in this century. The current globalization coerces our nation, specifically the younger generation. There are positive and negative impacts caused by globalization. The examples of negative impact of globalization are moral and character deterioration. Therefore, a concrete solution is needed to solve that issues. Historical learning is a lesson which laden of values and can be utilized as a medium for instill character values of the students. These values can be obtained by implemented an ancient manuscript scattered throughout the region in Indonesia. By combining several methods such as Group Investigation and Value Clarification Technique (VCT) as well as the existing values in the manuscript therefore a medium for solving moral and character can be created. This method is effectively accurate implemented to the XI-3 Social Science of SMA Negeri 1 Baureno by observing the improvement of leadership behavior and significant learning test result. In addition, this learning method can encourage other researcher to maintain and utilize ancestral heritage of ancient manuscript.

\section{References}

Abdurrahmansyah. 2004. Wacana Pendidikan Islam: Khasanah Filosofis dan Implementasi Kurikulum, Metodologi, dan Tantangan Pendidikan Moralitas. Yogyakarta: Global Pustaka Utama.

Adisusilo, Sutarjo. 2013. Pembelajaran Nilai Karakter, Konstruktivisme dan VCT Sebagai Inovasi Pendekatan Pembelajaran Afektif. Jakarta: PT Raja Grafindo Persada

Creswell, John W. 2009. Research Design: Qualitative, Quantitative, and Mixed Methods Approaches. Los Angeles: SAGE

Djahiri, Kosasih. 1985. Strategi Pengajaran Afektif-Nilai-Moral VCT dan Games dalam VCT. Bandung: PMPKN FPIPIS IKIP Bandung.

Goleman, D. 2003. Kepeemimpinan yang Mendatangkan Hasil. Cetakan Pertama. Yogyakarta: Amara Books.

Isjoni. 2007. Pembelajaran Sejarah Pada Satuan Pendidikan. Bandung : Alfabeta

Kartono, Kartini. 2005. Pemimpin dan Kepemimpinan. Jakarta: Raja Grafindo Persada

Kemendikbud. 2013. Pendekatan, Jenis Dan Metode Penelitian Pendidikan. Jakarta: T.P.

Margana, Sri. 2004. Pujangga Jawa dan Bayang-Bayang Kolonial. Yogyakarta: Pustaka Pelajar.

Moedjiono, dkk. 1992. Strategi Belajar Mengajar. Jakarta: Depdikbud.

Moertono, Soemarsaid. 1985. Negara dan Usaha Bina-Negara Di Jawa Masa Lampau. Jakarta: Yayasan Obor Indonesia.

Muslich, Masnur. 2011. Pendidikan Karakter: Menjawab Tantangan Krisis Multidimensional. Jakarta: PT Bumi Aksara. 
Poerwadarminta, W.J.S. 1939. Basoesastra Jawa. Batavia: J.B. Wolters’ Uitgevers Maatschappij

Purbadipura, Purbadipura. 1927. Serat Mudhatanya. Surakarta

Sa’ud, Udin Saifudin. 2008. Inovasi Pendidikan. Bandung: Penerbit Alfabeta.

Soekanto, Soerjono. 2000. Sosiologi Suatu Pengantar. Jakarta: PT Raja Grafindo Persada

Sugiyono, Sugiyono. 2015. Model Penelitian \& Pengembangan. Bandung: Alfabeta

Toeti Sukamto \& Udin Saripudin Wiranataputra. 1996. Teori Belajar dan Pembelajaran. Pusat Antar Universitas Untuk Peningkatan dan Pengembangan Aktivitas Instruksional. Dirjen Dikti Depdikbud.

\section{Journal}

Sariyatun, Sariyatun. 2013. "Pengembangan Model Pembelajaran Nilai-Nilai Budaya Di SMP Berbasis Tradisi Seni Batik Klasik Surakarta”. Paramita Vol. 23 No. 2- Juli 2013.

Sander, Tom J \& Kimberly S Davey. 2011. "Out of the leadership theory jungle: a Proposed model of strategic Leadership" Proceeding of the Academy of Srategic Management, Volume 10, Number 1 Orlando, 2011.

Suryani, Nunuk. 2013. "Pengembangan model internalisasi nilai karakter dalam pembelajaran sejarah melalui model Value Clarificaion Technique". Paramita Vol. 23 No. 2 - Juli 2013.

\section{Copyrights}

Copyright for this article is retained by the author(s), with first publication rights granted to the journal.

This is an open-access article distributed under the terms and conditions of the Creative Commons Attribution license (http://creativecommons.org/licenses/by/4.0/). 